\begin{tabular}{|lll|}
\hline \multicolumn{3}{|c|}{ TOTOBUANG } \\
\hline Volume 6 & Nomor 1, Juni 2018 & Halaman 47-58 \\
\hline
\end{tabular}

\title{
KONSTRUKSI SOSIAL PEPATAH TRADISIONAL DAN ATURAN ADAT UNTUK KESEIMBANGAN EKOLOGI \\ (Social Construction of Traditional Proverb and Customary Law For Balancing Ecology)
}

\author{
Dina Amalia Susamto \\ Badan Pengembangan dan Pembinaan Bahasa \\ Jalan Daksinapati Barat IV, Rawamangun Jakarta Timur \\ Pos-el: dina.susamto@gmail.com
}

(Diterima: 28 Mei 2018; Direvisi 30 Mei 2018; Disetujui: 5 Juni 2018)

\begin{abstract}
Traditional proverb is a language expression that is used as a tool to legitimize knowledge in a society. Lombok people have local knowledge that came from proverb and customary law that solved the ecology's problem that increase today. Language ass traditional proverbs and customary law are used as the tools to construct people's thought toward social awareness through internalization. The study aimed to analyze the proverb and costumary law which has used as the tools to construct social awareness. The study also discussed about kinds of traditional proverbs and customary law and their appearance, how the social contruction which related to ecology could construct people's awareness in west Nusa Tenggara through proverbs and customary law, and how individual and society practiced their culture, such as keeping ecology, after internalizing the values. . The results showed that the change of social structure that caused by the change of dinamical power had contributed to knowledge and people's awareness of the environment. Language was the representative of the symbolical legitimation of the law which was expressed in traditional proverbs and custamry law. These proverbs and customary law are used to construct people's awareness from generation to generation through internalizing the values..
\end{abstract}

Keywords: Traditional Proverb and Custamary Law, social Construction, ecology

\begin{abstract}
Abstrak
Pepatah tradisional merupakan ekspresi berbahasa yang menjadi sarana dalam legitimasi pengetahuan masyarakat. Masyarakat Lombok memiliki pengetahuan lokal yang berasal dari pepatah tradisional dan hukum adat yang dapat mengatasi masalah-masalah ekologi yang kini semakin meningkat. Bahasa dalam ungkapan tradisional dan hukum adat digunakan sebagai alat untuk mengonstruksi pola pikir masyarakat terhadap kesadaran sosial melalui proses internalisasi. Penelitian ini bertujuan untuk menganalisis pepatah tradisional dan hukum adat yang digunakan sebagai alat untuk mengonstruksi kesadaran sosial. Permasalahan yang dibahas adalah pepatah tradisional dan hukum adat apa saja yang muncul dan bagaimana konteks kelahirannya, bagaimana konstruksi sosial yang berhubungan dengan ekologi bekerja melalui ungkapan tradisional dan hukum adat untuk membentuk kesadaran masyarakat Nusa Tenggara Barat, dan bagaimana praktek budaya, dalam diri individu dan masyarakat, seperti menjaga ekologi di Nusa Tenggara Barat, setelah nilai-nilai itu terinternalisasi. Hasil penelitian menunjukkan bahwa struktur sosial yang berubah di masyarakat sebagai akibat dari dinamika kekuasaan yang berubah telah berkontribusi terhadap pengetahuan dan membentuk kesadaran masyarakat terhadap lingkungan hidup. Bahasa merupakan representasi simbol legitimasi aturan masyarakat yang muncul dalam pepatah tradisional dan hukum adat. Pepatah tradisional dan hukum adat digunakan untuk mengonstruksi kesadaran masyarakat dari generasi ke generasi melalui proses internalisasi nilai.
\end{abstract}

Kata-Kata Kunci: Pepatah Tradisional dan Hukum Adat, Konstruksi Sosial, Ekologi

\section{PENDAHULUAN}

Bahasa sampai saat ini masih kuat sebagai representasi dari realitas yang paling dasar. Ketika sebagian masyarakat memiliki pengetahuan tertentu untuk mengatasi masalah-masalah ekologi, bahasa digunakan sebagai sarana legitimasi pengetahuan yang telah dilembagakan oleh masyarakat. Sementara, pengetahuan yang hadir dalam masyarakat berubah dari waktu ke waktu 
seiring dengan konteks kesejarahan masyarakat. Perjumpaan masyarakat dengan negara, agama, dan sistem ekonomi kapitalisme mengubah nalar masyarakat termasuk cara pandang masyarakat terhadap ekologi.

Isu bencana ekologi merupakan salah satu isu terhangat di dunia ketika masyarakat modern dengan pola pikir rasionalitas instrumental telah berjarak dengan alam, menganggap alam sebagai objek yang dapat dieksploitasi untuk keuntungan sebesar-besarnya manusia tanpa memikirkan keseimbangan. Bencana ekologi telah mematikan sendi-sendi kehidupan mendasar manusia dengan akibat kerugian. Di Lombok Barat, Nusa Tenggara Barat sebagai salah satu daerah pengamatan penelitian, kerusakan ekologi terjadi pada penyempitan lahan hutan mangrove. Wahyudewantoro (2018) mengatakan bahwa berkurangnya jumlah lahan mangrove disebabkan oleh meningkatnya pembangunan di daerah pantai, turisme, dan budidaya air laut. Laman Asia Ifad.org pada 12 Desember 2012 memberitakan pola penyusutan luasan ekosistem mangrove di Kabupaten Lombok Barat yang seharusnya memiliki potensi mangrove seluas 606,81 ha, berdasarkan hasil pendataan terlihat bahwa kategori kondisi mangrove rusak berat seluas 487,98 ha, dan rusak ringan 118,83 ha. Riggs, dkk. (2018) mengatakan sejak tahun 1990 hutan-hutan di Lombok telah beralih fungsi $28.6 \%$. Masyarakat bergantung pada hutan untuk keberlangsungan air, kayu bakar, kayu, dan produk hutan nonkayu. Layanan regulasi ekosistem di dalamnya termasuk pencegahan banjir, pengendalian erosi, dan penyerbukan tanaman inti. Masyarakat juga menetapkan nilai-nilai adat untuk tujuan seremoni di hutan dan juga mendapat pendapatan dari peariwisata atas keberadaan hutan tersebut.

Masalah ekologi bersumber dari pola pikir masyarakat yang menempati suatu wilayah atau bentang alam. Bentang alam yang telah rusak bisa ditelusuri dari bagaimana nalar masyarakat memandang lingkungannya dan termanifestasi dalam bahasa dan tindakan atau praktik budaya dalam hidup sehari-hari. Di beberapa daerah di Indonesia, pola pikir tentang keseimbangan ekologi muncul dalam narasinarasi seperti mitos, legenda, pepatah tradisional bahkan dalam bahasa yang denotatif seperti hukum adat yang semuanya merupakan bagian dari tradisi lisan.

Pepatah tradisional dan hukum adat yang menjadi subjek penelitian ini ranah bahasa dan sastra yang mengandung nilainilai kemanusiaan, sosial dan budaya juga terdapat pesan moral, anjuran serta harapan untuk menjaga kelestarian alam dan lingkungan, termasuk bencana ekologi yang disinggung pada pernyataan sebelumnya. Darman (2017:244) menyatakan sastra merupakan cabang ilmu yang sangat dekat dengan manusia sebagai subjek yang mengambil peran penting dalam hal penyelamatan lingkungan. Menurutnya, penyelamatan lingkungan bukan hanya masalah perlindungan lingkungan secara fisik tetapi juga berkaitan dengan etika hidup manusia.

Penelitian tentang pepatah tradisional dan hukum adat mendiskusikan empat hal yaitu ungkapan tradisional dan hukum adat apa sajakah yang digunakan sebagai alat legitimasi institusi, bagaimana konteks kemunculan pribahasa tradisional dan hukum adat yang berhubungan dengan perlindungan ekologi di daerah Nusa Tenggara Barat, bagaimana konstruksi sosial yang berhubungan dengan ekologi bekerja dalam membentuk kesadaran masyarakat di Nusa Tenggara Barat melalui ungkapan tradisional dan tata aturan adat, dan bagaimanakah praktik budaya dalam diri individu dan masyaraskat setelah proses internalisasi nilai-nilai menjaga ekologi di Nusa Tenggara Barat.

Penelitian kajian sastra lisan di beberapa daerah di Indonesia, khususnya di Nusa Tenggara memiliki tujuan untuk mendeskripsikan bahasa sebagai alat 
legitimasi institusi dalam ungkapan tradisional dan hukum adat dan menjelaskan konteks kemunculan ungkapan tradisional dan hukum adat yang berhubungan dengan perlindungan ekologi di daerah Nusa Tenggara Barat, menjelaskan proses konstruksi sosial yang berhubungan dengan ekologi bekerja dalam membentuk kesadaran masyarakat di Nusa Tenggara Barat melalui ungkapan tradisional dan hukum adat, serta mendeskripsikan praktik budaya dalam diri individu dan masyaraskat setelah proses internalisasi nilai-nilai menjaga ekologi di Nusa Tenggara Barat.

Penelitian-penelitian sebelumnya antara lain, Asrif La Madira (2015) tentang Wacana Mitos Imbu terhadap Pelindungan Alam laut Masyarakat Kepulauan Wakatobi. Andi Achdian (2015) Leuwung Hejo Masyarakat Ngejo (Hutan Hijau Masyarakat Sejahtera): Konstruksi Politik Hijau dan Siasat Politik Kontemporer dalam Tradisi Lisan Masyarakat Kasepuhan Kawasan Hutan Lindung Gunung Halimun, Kabupaten Lebak, Provinsi Banten. Hadirman (2015) dalam Mengkreasi Produk Kajian Ekolinguistik terhadap Tradisi Lisan Kabjanti di Muna: Menuju ke Arah Penguatan Kajian Eco-Oral Tradition dan Taena dkk (2016) tentang tradisi Falia yang dimiliki etnik Muna dalam menjaga hutan.

Asrif dalam tulisan tersebut mengangkat isu keefektifan mitos gurita raksasa berlengan sembilan yang mampu membunuh siapapun yang merusak lingkungan laut yang masih diyakini masyarakat hingga hari ini. Ingatan masyarakat pada mitos yang menjadi pengawas masyarakat kemudian menciptakan relasi keseimbangan yang positif antara manusia dan alam laut.

Andi Achdian mengungkap aspekaspek ritual, aturan lisan hingga klaim sejarah berabda-abad sebagai usaha melindungi diri ketika masyarakat kasepuhan di kawasan hutan lindung Gunung Halimun harus berhadapan dengan kekuatan negara dan pasar, sedangkan
Hardiman mengatakan bahwa perubahan bahasa dalam kabhanti menggambarkan perubahan ekologi baik alamiah maupun ekologi manusia dan budaya secara luas. Kabhanti sangat khas dengan penggunaan leksikon, frasa dan wacana yang mewadahi keberagaman hayati, flora dan fauna. Taena dkk. dalam pembahasan tradisi Falia pada suku Muna mengatakan bahwa tradisi falia mengontrol prilaku masyarakat Muna terhadap dalam memperlakukan hutan dengan keyakinan bahwa siapa pun yang merusak hutan akan mendapat hukuman secara supranatural salah satunya datangnya berbagai penyakit dan malapetaka lain.

Penelitian-penelitian di atas menunjukkan sumbangan tradisi lisan pada penjagaan lingkungan hidup. Akan tetapi keseluruhan penelitian tersebut belum membahas bagaimana proses penumbuhan kesadaran masyarakat melalui bahasa sebagai alat konstruksi sosial yang diwujudkan dalam pepatah tradisional dan hukum adat. Penelitian ungkapan bahasa termasuk di dalamnya tata aturan adat bagian dari tradisi lisan yang memiliki pesan verbal yang disampaikan dan dimaknai oleh anggota masyarakat. Dengan menggunakan kerangka teori konstruksi sosial, peneliti melihat bahwa pepatah tradisional, mitos dan larangan adat, termasuk hal-hal yang tabu merupakan pengetahuan yang hidup di tengah masyarakat. Proses pengetahuan yang berhubungan dengan penjagaan lingkungan hidup berada dalam masyarakat merupakan masalah yang didiskusikan dalam penelitian ini melalui bahasa sebagai alat pengonstruksi nalar masyarakat. Bahasa memberikan legitimasi langsung untuk mempertahankan institusi seperti lembaga adat yang membakukan aktivitas-aktivitas budaya masyarakat seperti ritual-ritual untuk menjaga lingkungan hidup.

Pesan-pesan yang dinarasikan menggunakan bahasa dalam bentuk pepatah, tabu, aturan adat diinternalisasikan ke dalam diri masyarakat, yang berujung pada usaha 
membentuk pola pikir, keyakinan dan menjaga prilaku masyarakat dan terus diwariskan. Aturan adat dan ungkapan bekerja sebagai pengawas dalam individu dan masyarakat. Satu sisi, pesan tersebut kemudian direspon oleh masyarakat setempat dalam bentuk praktik-praktik budaya seperti melakukan ritual untuk tetap seimbang dengan alam, mematuhi tabu-tabu dalam tindak tutur dan prilaku sehari-hari.

\section{LANDASAN TEORI}

Kontruksi sosial, sebuah konsep yang dipinjam dari ilmu sosial yang dikembangkan oleh Berger dan Luckmann (1967) menyatakan bahwa realitas adalah konstruksi sosial. Realitas dalam pandangan Berger dibagi dalam realitas yang objektif dan subjektif. Pertama, realitas yang objektif di dalamnya terdapat struktur sosial yang merupakan ranah yang membuat kehidupan manusia teratur dan tentram, diantaranya terdapat institusi dan tindakan sosial. Struktur sosial menjadi patokan manusia dalam berpikir dan bertindak meskipun tidak membatasi tindakan manusia yang subjektif. Kemudian kedua, realitas subjektif, yaitu isi atau makna struktur sosial yang dapat dipahami dari sudut pandang anggota masyarakat yang berada di bawah naungannya.

Proses konstruksi sosial berlangsung dalam cara bagaimana suatu pengetahuan bisa berada di tengah masyarakat. Berger menjelaskan proses pembentukan realitas sosial berada di dalam kesadaran manusia. Realitas dibentuk oleh kesadaran manusia dengan merujuk pada relasi logis fakta-fakta yang dialaminya. Salah satu fakta yang dialami manusia adalah kebutuhan hidup. Kebutuhan tersebut repetitif hingga terbentuknya kaidah atau institusi untuk mengorganisasi pemerolehan kebutuhan tersebut sehingga tercipta rasa aman. Berger dalam Riyanto (2009) mengatakan dalam pemenuhan kebutuhan terjadi interaksi individu dengan masyarakat yang prosesnya melalui ekternalisasi (objektivikasi) dan internalisasi. Pembentukan institusi ini disebut ekternalisasi, sedangkan internalisasi adalah proses ketika manusia dibentuk atau produk dari masyarakat. Internalisasi ini memiliki fungsi mentransmisikan intitusi kepada anggota masyarakat agar institusi tersebut (dan perangkat aturannya) tetap bertahan dari waktu ke waktu. Manusia yang mengonsepsikan institusi tersebut juga terus mengalami internalisasi agar status objektivitas institusi yang dikonsepkan dalam kesadaran tetap kukuh. Dengan demikian hubungan dialog manusia dan masyarakat adalah manusia membentuk masyarakat dan manusia dibentuk oleh masyarakat.

Institusi yang hadir membutuhkan legitimasi atau pengesahan untuk menjelaskan secara kognitif alasan adanya institusi itu. Legitimasi memiliki empat tingkatan yang semakin tinggi tingkatannya menunjukkan legitimasi tersebut bersifat koheren dan teoritis. Tingkatan pertama legitimasi adalah bahasa. Bahasa merupakan representasi dari realitas yang paling dasar. Bahasa memberikan legitimasi langsung untuk mempertahankan institusi. Tingkatan kedua, bahasa yang diwujudkan dalam pepatah atau ungkapan yang konotatif. Tingkatan legitimasi ketiga adalah teori yang dirumuskan masyarakat yang sudah sangat memahami masalah-masalah terkait, misalnya pemimpin spiritual yang memahami diadakannya ritual. Legitimasi teoritis ini disebut tatanan simbolik atau symbolic order yang dicontohkan dengan agama (keyakinan) atau melalui paradigma ilmu pengetahuan. (Berger dalam Riyanto, 2009)

Selain Berger dan Luckmann, pada tahun 1991 Bruner megemukakan konsep konstruksi narasi. Antara konstruksi narasi dan konstruksi sosial mempunyai titik temu pada hubungan antara konstruksi sosial terhadap realitas dan interaksi manusia sebagai subjek yang melakukan konstruksi terhadap realitas. Menurut Bruner konstruksi realitas disokong oleh prinsip-prisip dan 
prosedur yang berupa perlatan tradisi yang dimodelkan dan disebarluaskan. Pengalaman manusia disusun dalam narasi-narasi yang berbentuk cerita rakyat, mitos, alasan untuk melakukan sesuatu atau tidak, dan sebagainya.

$\begin{array}{rrr}\text { Mengkonstruksi } & \text { realitas } & \text { dengan } \\ \text { narasi membutuhkan } & \text { bahasa. } & \text { Bruner }\end{array}$ menekankan bahwa manusia membangun ide-ide satu sama lain, mengalami peristiwa bersama, dan memiliki memori dalam kehidupan sehari-hari dalam bentuk narasi. Narasi merupakan versi dari realitas dan instrumen pikiran yang digunakan sebagai alat pengkonstruksian. Konstruksi sosial dan konstruksi narasi menghubungkan tradisi lisan dengan realitas dalam kehidupan sehari-hari.

\section{METODE}

Penelitian ini di wilayah field research (riset lapangan) pada tanggal 6-10 Oktober 2015 di Lombok dengan pendekatan kualitatif yang dilakukan dengan cara melakukan wawancara kepada beberapa jenis informan. Hasil-hasil data pengumpulan ungkapan tradisional dan aturan adat kemudian ditranskripsi dan dianalisis dengan kerangka konstruksi sosial. Data-data yang didapatkan dari riset lapangan menjadi data primer, sedangkan sumber data sekunder sebagai sumber data penunjang dalam penelitian ini adalah datadata yang diperoleh dari studi kepustakaan baik dari buku-buku maupun sumber lain.

\section{PEMBAHASAN}

\section{Struktur sosial budaya Komunitas}

Struktur sosial budaya komunitas mencakup pelembagaan kebiasaan atau habituasi. Pelembagaan bagian dari upaya mempertahankan pola-pola yang dianggap akan memberi keteraturan, dan ketenangan. Pembiasaan merupakan proses yang terusmenerus dijalani, kemudian dibuat aturan dan kontrol terhadap aturan tersebut. Ritual merupakan pola yang diulang-ulang oleh masyarakat yang kemudian dibuat sistematikanya oleh pelaku-pelaku yang berkepentingan terhadap ritual tersebut untuk terus diajarkan dan diingat oleh masyarakat. Sedangkan aturan adat bagian dari mekanisme pengontrolan sesuatu yang dilakukan sebagaimana biasa untuk tujuan tertentu. Dengan demikian dalam pelembagaan terdapat dua sisi yaitu tindakan yang dibiasakan dan pelaku yang mempraktikkan termasuk yang memimpin atau mengontrol.

Bentang geografis laut, gunung di tempat hidup masyarakat Sasak di Lombok menimbulkan kelahiran lembaga adat untuk mengatur, dan menyelesaikan persoalan yang berhubungan dengan bentang alam tersebut. Misalnya, dalam masyarakat Lombok pelembagaan terhadap kebiasaan mensucikan air laut timbul upacara bau nyale. Pengaturan ritual itu sendiri supaya terus menerus bisa dilaksanakan yang kemudian menimbulkan kebutuhan akan lembaga yang mengurus tata upacara keagamaan. Lembaga adat masyarakat Sasak yang setelah kedatangan Islam mensikretikkan ajaran-ajaran atau aturan yang dikosepsikan dalam pikiran masyarakat Sasak terdiri dari pemuka adat. Pemuka adat bertugas mengatur aspek Watu Telu, suatu kepercayaan sinkretik antara Islam, Hindu dan agama pagan masyarakat. Pemuka adat disebut pemangku. Meskipun pemangku dalam hirarki masyarakat Sasak bukan dari golongan bangsawan, tetapi pemangku adalah petugas adat yang penting dalam komunitas yang bertugas dalam setiap upacara.

Pada komunitas Sasak terdapat kelompok-kelompok pemangku di antaranya pemangku gubug yang mengurusi perumahan komunitas ketika memperantarai hubungan komunitas dengan dunia spritual. Pemangku aiq mengurusi pertanian Subak yaitu proses pengairan dari mata air yang membutuhkan tata cara spiritual dalam pelaksanaan pengairan dari mata air. Kelompok pemangku ini menjaga tata cara yang diajarkan dari sistem kepercayaan yang 
juga sudah dilembagakan, yaitu Watu Telu. Pemangku merupakan struktur yang berada di bawah para bangsawan.

Bangsawan dalam lembaga adat Sasak menempati posisi tertinggi dalam keyakinan masyarakat. Masyarakat yang mempercayai kekuatan supranatural melanggengkan pelembagaan sistem sosial bertingkat berdasarkan referensi kosmologi sinkretis Watu Telu. Struktur ini juga menentukan kepemilikan tanah. Bangsawan berhak mengusai tanah-tanah atas nama adat. Strata ini dilembagakan sebagai suatu cara menjaga kemurnian bangsawan sehingga tetap berada dalam posisi tertiggi di atas masyarakat biasa. Perkawinan endogami atau perkawinan sesama kelompok yang setara merupakan usaha mempertahankan posisi tertinggi tersebut. Jika terdapat bangsawan yang melakukan perkawinan eksogami dianggap telah mengkhianati leluhur yang akibatnya bangsawan tersebut kehilangan kekuatan supranatural. Dalam struktur komunitas tersebut posisi perempuan bangsawan menjadi sangat penting dalam menjaga kelestarian perkawinan endogami. Akan tetapi posisi kebangsawan pada masyarakat Lombok sekarang sudah mengalami transformasi sosial seiring dengan masuknya ajaran Islam yang tidak mempercayai sistem kekastaan.

Struktur sosial budaya komunitas sasak yang menganut Islam awal di Lombok terdiri dari Tuan Guru yang menjadi panutan bagi masyarakat. Tuan Guru adalah orang yang mempunyai keilmuan di bidang agama Islam. Tidak hanya panutan dalam bidang ilmu agama, Suprapto (2015) mengatakan, Tuan Guru juga memegang peran penting dalam integrasi masyarakat Sasak dan menyelesaikan konflik apabila terjadi konflik etnik dan agama di P. Lombok. Di masa awal, Tuan Guru berasal dari kalangan pedagang yang menyebarkan Islam melalui perdagangan di wilayah pesisir yang kebanyakan berasal dari kesultanan Makasar. Di masa berikutnya ketika banyak bangsawan Sasak dari kedatuan Selaprang belajar ilmu Islam hingga ke negeri Arab di Mekah mereka juga menjadi tokoh-tokoh perubahan sosial masyarakat Sasak. Tidak hanya bidang transformasi sosial, peran Tuan Guru juga pemimpin peperangan melawan kerajaan Bali yang berkuasa di wilayah Barat, juga pemimpin perjuangan melawan penjajahan Belanda.

Salah satu Tuan Guru yang sangat berpengaruh dalam masyarakat Sasak adalah TGKH Syaikh Muhammad Zainuddin Abdul Madjid, pendiri Nahdlatul Wathan, organisasi massa Islam yang terbesar di provinsi Nusa Tenggara Barat / NTB. Adawiyah (2009) mencatatkan biografi Tuan Guru Zainuddin dalam tesis berjudul Pendidikan Pesantren Menurut Pemikiran Tuan Guru Kyai Haji Muhammad Zainuddin Abdul Madjid. Adawiyah mengatakan bahwa setelah belajar di Mekah selama 6 tahun di Madrasah Ash Shaulatiyah yang dipimpin oleh Syaikh Salim Rahmatullah, Tuan Guru Zainuddin kembali ke Lombok dan mendirikan Madrasah Al Mujahidin (1934 M. Madrasah ini kemudian menjadi pokok berdirinya organisasai agama terbesar di NTB yaitu Pondok Pesantren Nahdlatul Wathan (NW), yang menjadi perintis dan penggerak sosial keagamaan di Lombok dan Sumbawa. Pondok pesantren NW kemudian melahirkan banyak kalangan yang terdisik di Lombok dan Sumbawa yang menjadi agen perubahan sosial pada masyarakat Lombok saat ini.

Di samping Tuan Guru atau disebut Lokaq atau Kyai yang danggap pemegang kosmos, struktur sosial masyarakat Sasak masa Islam awal dibantu oleh pemegang pemegang hukum yaitu Penghulu, pemegang wilayah yaitu Pembekel, dan Pemegang Keahlian Balian. Di masa sekarang ketika dalam masa administratif pemerintahan RI, pemerintahan administratif seperti kepala desa berperan dalam memegang pimpinan pemerintahan di tingkat desa. Akan tetapi kehidupan sosial masyarakat di masa administrasi modern 
juga banyak dipengaruhi oleh kehidupan organisasi politik yang wilayah kerjanya sampai ke desa-desa terutama saat akan diadakannya pemilihan umum. Struktur pemerintahan nasional dalam era media massa dan elektronik menjadi pelaku-pelaku transformasi sosial di masa kini. Tuan Guru masih memiliki wibawa yang sangat besar sebagai pelaku perubahan, bahkan partaipartai politik berlomba melakukan pendekatan terhadap Tuan-Tuan Guru dalam rangka mendapat dukungan dengan demikian tujuan praktis memenangkan pemilihan umum.

Ajaran-ajaran yang disampaikan Tuan Guru telah mengubah pola pikir masyarakat di Lombok termasuk pola pikir terhadap lingkungan hidup. Watu Telu yang singkretik dengan budaya masyarakt lokal memulaikan alam karena sistem kepercayaan bahwa alam mengandung kekuatan yang harus ditakuti. Pada masa islam berikutnya yang diajarkan Tuan Guru pada masa awal masih bercorak esoteris, yakni islam dengan pendekatan sufisme yang membuka keyakinan pada hubungan kedekatan dengan alam. Tetapi masa Tuan Guru akhir pada abad pertengahan 20, Islam dengan pendekatan eksoteris atau hukum syariah menjadi lebih dominan dan menghapus kepercayaan-keperayaan yang menurut islam ini bid'ah. Islam eksoteris membuka pola pikir baru tentang ekologi yang bersifat penguasaan, karena kekuatannya menundukkan alam dan segala praktik budaya yang tunduk pada alam.

\section{Bahasa dalam Ungkapan Tradisional sebagai Representasi Simbolik Legitimasi Aturan}

Bentang alam baik laut, dataran pegunungan maupun dataran rendah di Pulau Lombok diatur dalam ungkapan atau tata aturan adat yang merupakan derivasi dari konsep kosmologi masyarakat Sasak. Gumi Paer yang merupakan lokus geografis bagi masyarakat Sasak yang tinggal di atasnya melahirkan pranata-pranata sosial yang dilembagakan disahkan atau dilegitimasi melalui bahasa.

Ungkapan atau Tata Aturan Adat merupakan ekspresi peligitimasian pranatapranata sebagai konsekwensi komitmen hidup bersama. Komitmen yang muncul dari institusionalisasi kebiasaan hidup sehari-hari dibakukan oleh masyarakat dalam bentuk tata aturan adat dan ungkapan berbahasa. Dalam bidang ekologi di Lombok terdapat ungkapan atau tata aturan adat yang mengatur hubungan antara manusia dan alam. Tata aturan adat ini menghasilkan istilah mali atau tabu untuk dilanggar.

\section{Pelindungan Laut}

Dalam masyarakat Sasak dikenal dengan ungkapan seda' karangseda` diri. Ungkapan ini berarti merusak batu karang itu sama dengan merusak diri sendiri. Selain ungkapan itu terdapat juga Dendek pade sedak karang-karang lek segare yang berarti dilarang merusak terumbu karang di laut dan ungkapan endak lepas jaring elek sedi laun ede karang dekne arak taok mpak bebale yang berarti jangan tebar jala di pinggir laut nanti tidak ada tempat ikan bersarang.

Terumbu karang bagian dari habitat mahluk laut. Terumbu karang merupakan suatu ekosistem yang menunjang kehidupan berbagai jenis makhluk hidup yang ada di sekitar terumbu karang. Dengan adanya terumbu karang maka tumbuhan dan hewan laut lainnya dapat tinggal, mencari makan dan berkembang biak di terumbu karang. Menurut penjelasan yayasan di bidang penyelamatan terumbu karang yang dipublikasikan dalam laman http://www.terangi.or.id, terumbu karang memiliki biodiversitas tertinggi dalam tingkatan filum. Terumbu karang juga merupakan ekosistem dengan biodiversitas tertinggi dibandingkan ekosistem pesisir dan laut lainnya, dalam unit skala tertentu. Artinya dalam luas $1 \mathrm{~km}^{2}$ di wilayah terumbu karang mengandung lebih banyak spesies dibandingkan dengan $1 \mathrm{~km}^{2}$ di 
wilayah laut dalam. Tingkat biodiveristas terumbu karang yang tinggi akan menjadi sumber keanekaragaman genetik dan spesies. Keanekaragaman genetik yang dimaksud di sini banyaknya variasi dalam makhluk hidup sehingga tingkat ketahanan terhadap penyakit dan kemampuan bertahan hidup suatu makhluk hidup dapat menjadi lebih tinggi. Selain itu dengan begitu banyaknya spesies maka akan dapat dimanfaatkan untuk sebagai sumber pangan dan obat-obatan.

Terumbu karang juga benteng pertama yang melindungi pantai. Terumbu karang, padang lamun dan hutan bakau merupakan ekosistem yang saling berhubungan. Terumbu karang merupakan tumbuhan yang pertama kali menghalau ombak besar dari laut, agar tidak merusak daratan. Kemudian ombak tiba di padang lamun maka energinya akan diperkecil lagi oleh daun-daun tumbuhan lamun. Ketika ombak tiba di dekat pantai, maka akar dan batang pohon-pohon mangrove akan memperkecil lagi energi ombak, sehingga ombak tidak merusak pantai. Terumbu karang bermanfaat dalam menghalangi pengikisan akibat energi ombak dan arus, sehingga masalah abrasi pantai yang mengikis daratan pulau-pulau akan lebih mudah diatasi. Bahkan artikel tersebut juga menjelaskan bahwa terumbu karang juga berfungsi mengurangi pemanasan global seperti hutan hujan tropis, terumbu karang menyerap gas $\mathrm{CO}_{2}$ hasil pembakaran sehingga mengurangi pemanasan pada bumi, mencegah perubahan iklim.

Bagi masyarakat Sasak kosmologi laut yang dianggap suci dibahasakan dengan ungkapan-ungkapan dan larangan antara lain dilarang membuang kotoran manusia di laut, nanti tidak akan melihat kotoranmu lagi. Disucikannya laut bagi orang Sasak juga menimbulkan ungkapan-ungkapan atau aturan adat yang dilarang berzina di laut, dan dilaranag membawa perempuan ke laut ketika menstrusasi.
Larangan pergi ke laut di hari Jumat supaya laki-laki menjalankan peribadatan salat Jumat. Larangan tersebut mempunyai pendasaran keseimbangan bagi manusia antara mencari nafkah dan peribadatan. Larangan bertengkar di laut, dan larangan menyebut gurita ketika berada di laut. Gurita adalah binatang yang menakutkan bagi nelayan Sasak yang dapat membunuh manusia. Gurita yang dimaksud adalah bagian dari epen laut atau mahluk halus dalam laut yang dipercayai sebagai sesuatu yang menakutkan. Oleh karena itu dianggap tabu menyebut gurita secara verbal sebagai nama panggilannya ketika sedang berada di laut. Sedangkan bertengkar di laut menandakan hawa nafsu yang tidak boleh diperturutkan ketika di laut karena akan berakibat tidak saja ikan yang sedang dicari akan hilang atau tidak jadi menjadi rezeki tetapi berakibat merusak hubungan sesama manusia atau nelayan yang sedang bersamasama berangkat mencari ikan di laut.

\section{Pelindungan Hutan dan alam lingkungan sekitar}

Hutan di sekitar kawasan Gunung Rinjani di Sembalun, Lombok Timur memiliki tata hukum adat salah satunya larangan tidak boleh membawa makananmakanan yang berbumbu. Makanan berbumbu mengandung hawa panas yang dan merusak rumput-rumut di bawah pohon. Rumput-rumputan adalah tanaman penutup permukaan tanah untuk melindungi tanah dari ancaman kerusakan oleh erosi dan / atau untuk memperbaiki sifat kimia dan sifat fisik tanah. Tanaman penutup tanah berperan: (1) menahan atau mengurangi daya perusak butir-butir hujan yang jatuh dan aliran air di atas permukaan tanah, (2) menambah bahan organik tanah melalui batang, ranting dan daun mati yang jatuh, dan (3) melakukan transpirasi, yang mengurangi kandungan air tanah. Peranan tanaman penutup tanah tersebut menyebabkan berkurangnya kekuatan dispersi air hujan, mengurangi jumlah serta 
kecepatan aliran. Ketika daerah sekitar kawasan hutan Rijani menjadi area wisata, pemerintah membantu penjagaan ekologi sekitar hutan lindung Rinjani dengan menerapkan ekowisata. Bonita dalam Sadikin dkk. (2017) mengatakan bahwa aktivitas ekowisata berupa lintasan trekking menuju puncak Gunung Rinjani dan danau Segara Anak yang melewati zona larangan karena dapat menggagu flora dan fauna. Dengan demikian beberapa hal sangat perlu diperhatikan bagi para wisatawan antara lain dilarang memasak, membunyikan suara-suara dan membuat bebauan.

\section{Internalisasi Ungkapan/Tata Aturan Adat Pada Masyarakat}

Bagian ini membahas pelembagaan nilai-nilai ekologi dilakukan melalui proses internalisasi dalam pola pikir masyarakat. Internalisasi ungkapan/tata aturan adat berfungsi mentransmisikan institusi atau kebiasaan yang dilembagakan kepada anggota masyarakat agar institusi tersebut tetap bertahan.Internalisasi dilakukan dengan cara sosialisasi suatu kebiasaan. Paparan di bawah ini akan membahas mekanisme sosialisasi nilai-nilai penjagaan ekologi di Lombok dalam bentuk ritual.

Ritual adalah salah satu cara internalisasi ungkapan tradisional. Ritual atau upacara adat bagian dari sosialisasi nilai-nilai dalam hal ini yang berhubungan dengan penjagaan ekologi. Pada masyarakat Lombok dikenal upacara Metulak atau upacara menolak bala. Tulak artinya kembali. Metulak berarti mengembalikan. Upacara ini dikerjakan oleh masyarakat yang seketurunan berasal dari desa induk yang sama. Pada kesempatan ini upacara dilaksanakan di desa Pujut.

Upacara Metulak diadakan setiap empat tahun sekali. Jenis bala atau wabah yang ditolak adalah yang menyerang padi, ternak, juga wabah yag menimpa manusia. Tujuan upacara ini keselamatan seluruh manusia maka yang harus dilakukan adalah memelihara lingkungan tempat manusia hidup. Sebelum pelaksanaan upacara masyarakat bekerja bakti membersihkan lingkungan sekitar. Kerja bakti yang dilakukan rutin ini dan turun temurun ini memasukkan suatu kebiasaan pad masyarakat yang membentuk pola pikir tentang menjaga lingkungan untuk menolak bala.

Selain upacara Metula juga terdapat upacara bau nyale. Kata Nyale berasal dari nama sejenis cacing laut yang biasa hidup di dasar laut atau lubang-lubang batu karang. Masyarakat meyakini Nyale adalah jelmaan dari rambut Putri Mandalika, seorang putri raja di Pulau Lombok. Kecantikannya ternyata memukau banyak pangeran di Pulau Lombok sehingga banyak pinangan yang menghampiri dirinya. Karena bingung, Sang Putri memutuskan untuk menceburkan diri ke Pantai Selatan. Setelah kejadian tersebut, setiap tahun munculah Nyale yang dipercaya sebagai jelmaan dari rambut Putri Mandalika.

Bau Nyale merupakan ritual menangkap cacing laut yang biasanya keluar di daerah pantai Kuta pada bulan-bulan tertentu. Cacing-cacing yang berwarna hijau, coklat, oranye hingga merah ini akan keluar pada tengah malam hingga pagi hari ketika pesisir laut mulai surut. Ada 16 titik pantai di Selatan Lombok Tengah yang memanjang sejauh puluhan kilometer dari arah Timur hingga barat seperti di Pantai Kaliantan, Pantai Kuta atau Pantai Selong Belanak. Cacing yang ditangkap pada ritual ini nantinya akan dikonsumsi warga dengan dimasak dan dimakan bersama-sama.

Ritual bau nyale mensosialisasikan nilai menjaga lingkungan laut dengan demikian tidak hanya cacing-cacing yang tiap tahun dapat ditangkap dan dikonsumsi tetapi juga terjagaya terumbu karang dan ikan-ikan dan seluruh habitat pada ekosistem laut.

Sosialisasi penjagaan lingkungan hidup juga dilakukan oleh pemerintah dengan aturan Sassi. Aturan yang berbentuk perda tersebut bagian dari internalisasi 
menjaga laingkungan laut. Sassi merupakan aturan libur menangkap ikan selama beberapa hari yang berguna untuk memberi waktu pada ikan berkembang biak.

\section{Implikasi Ungkapan/Tata Aturan Adat Pada Masyarakat.}

Bagian ini akan menjelaskan sikap masyarakat terhadap ungkapan/tata aturan adat yang ditanamkan oleh institusi. Masyarakat baik di Bali dan Lombok saat ini sebagian besar masih meyakini pentingnya keseimbangan alam terutama pada masyarakat yang tinggal di wilayah lingkungan geografis pesisir pantai dan pegunungam, dan masih mengenal tata aturan adat dalam bentuk tabu. Bagian ini juga membahas pihak-pihak yang tidak menganggap bahwa keseimbangan ekologi itu penting.

Di Lombok masyarakat juga masih sangat takut melanggar pantangan-pantangan yang ditetapkan juga takut tidak menyelenggarakan ritual-ritual tertentu. Meskipun ajaran islam eksoteris yang menekankan syariah menyebar pada masyarakat Lombok, tetapi ajaran tersebut tidak mengurangi kepercayaan mereka pada tabu-tabu tertentu seperti tidak melaut di hari Jumat. Seorang nelayan yang tinggal di Lombok Timur mengatakan bahwa tiap hari Jumat ia tidak pergi melaut, juga pada saat ditetapkannya sassi. Akan tetapi tidak semua masyaakat di Lombok masih mempercayai dan mematuhi tabu-tabu tersebut. Agama Islam berperan penting dalam menggeser keyakinan masyarakat pada tabu sehingga ungkapan tradisional tidak memiliki makna lagi. Dinamika sosial kemunculan penguasapenguasa di Lombok yang berpengaruh terhadap masyarakat Lombok.

\section{PENUTUP}

Penelitian tentang ungkapan/tata aturan adat sebagai konstruksi sosial berbasis lingkungan hidup mempermasalahkan bahasa yang digunakan sebagai sarana pelegitimasian pengetahuan tentang ekologi yang telah dilembagakan oleh masyarakat. Pengetahuan membentuk pola pikir, sedangkan pengetahuan terus berubah seiring dengan perubahan kekuasaan atau struktur masyarakat yang menanamkan pengetahuan. Pola pikir masyarakat termanifestasi dalam bahasa dan tindakan atau praktik budaya dalam hidup sehari-hari.

Pengetahuan masyarakat tentang lingkungan hidup juga mengalami perubahan. Pandangan masyarakat tentang alam yang semula tunduk terhadap alam sebagian telah berubah pada penaklukan terhadap alam. Pandangan alam sebagai objek yang ditaklukkan mengakibatkan praktik hidup yangsemena-mena terhadap lingkunga hidup dan terjadi yang disebut dengan bencana ekologi. Isu bencana ekologi kini menjadi isu global yang membahayakan kesejahteraan umat manusia.

Berdasarkan latar belakang masalah tersebut terdapat tiga masalah yang didiskusikan antara lain pertama, sebagai alat legitimasi institusi, ungkapan tradisional/tata aturan adat apa saja dan bagaimana konteks kemunculan ungkapan tradisional/tata aturan adat yang berhubungan dengan perlindungan ekologi di Nusa Tenggara Barat. Kedua bagaimana konstruksi sosial yang berhubungan dengan ekologi bekerja dalam membentuk pola pikir masyarakat di Nusa Tenggara Barat dan Bali melalui ungkapan tradisional dan tata aturan adat. Ketiga, bagaimanakah praktik budaya dalam diri individu dan masyarakat setelah proses internalisasi nilai-nilai menjaga ekologi di Sumatera Barat, Nusa Tenggara Barat, dan Bali.

Hasil pembahasan masalah-masalah yang dirumuskan di atas antara lain bahwa struktur sosial yang berubah di masyarakat sebagai akibat dari dinamika kekuasaan yang berubah telah memberikan jejak pengetahuan dan membentuk pola pikir masyarakat terhadap lingkungan hidup. Pengetahuan tersebut diamati dari praktik 
budaya atau pembiasaan prilaku terhadap lingkungan hidup yang kemudian dilembagakan atau diinstitusikan. Pembiasaan tersebut dilegitimasi melalui bahasa yang muncul pada bentuk konotatif yaitu ungkapan dan denotatif yaitu tata aturan adat.

Bahasa merupakan representasi Simbolik Legitimasi Aturan Masyarakat yang muncul dalam nasehat yaitu ungkapan juga tabu dan tata aturan adat. Di Lombok aturan adat lebih dipraktikkan dalam kehidupan sehari-hari masyarakat, meskipun terdapat juga bahasa konotatif yaitu ungkapan. Ungkapan/tata aturan adat tersebut muncul dengan memiliki konteks kesejarahan masyarakat, dan sosial budaya.

Ungkapan/tata aturan adat sebagai alat pengkonstruksi sosial di dalam pola pikir masyarakat dilakukan melalui proses internalisasi. Bahasa berbentuk ungkapan/tata aturan adat yang meligitimasi suatu lembaga atau intitusi terus menerus ditransmisikan atau disosialisasikan pada masyarakat dengan cara penanaman kesadaran. Ritual-ritual merupakan cara yang rutin yang berfungsi mensosialisasikan tata aturan adat/ungkapan sehingga masyarakat selalu mengingat dan mempraktikkan aturan menjaga lingkungan hidup.

Kerusakan lingkungan hidup tetap terjadi daerah penelitian tersebut. Ini menunjukkan bahwa di tingkat praktik ada yang tidak sesuai antara ungkapan/tata aturan adat yang ditanamkan oleh struktur sosial kepada masyarakat dengan praktik budaya atau pola pikir yang ada di dalam masyarakat. Akan tetapi di tingkat masyarakat Lombok masih banyak masyarakat yang mempercayai dan mentaati aturan dan sadar pada keseimbangan alam. Pertanyaan yang muncul kembali setelah penelitian ini adalah masyarakat yang mana yang tidak mentaati dan struktur sosial yang mana yang tidak memperdulikan lagi ekologi. Persoalan struktur pemerintahan nasional dalam negara dan hubungan negara dengan korporasi-korporasi swasta belum dibahas dalam penelitian ini yang mungkin menjadi sebab kerusakan lingkungan. Korporasi yang dikembangkan berdasarkan bisnis yang meraih keuntungan sebanyakbanyaknya memiliki pola pikir yang berbeda terhadap alam dan memiliki legitimasi dalam bahasa yang berbeda.

\section{DAFTAR PUSTAKA}

Achdian, Andi. 2015. "Leuwung Hejo Masyarakat Ngejo (Hutan Hijau Masyarakat Sejahtera):Konstruksi Politik Hijau dan Siasat Politik Kontemporer dalam Tradisi Lisan Masyarakat Kasepuhan Kawasan Hutan Lindung Gunung Halimun, Kabupaten Lebak, Provinsi Banten", dalam Merayakan Keberagaman Tradisi Sebagai Warisan Budaya prosiding Seminar Internasional dan Festival Tradisi Lisan IX Wakatobi, 12-15 Juni 2015.

Adawiyah, Muazzatun. 2009. Pendidikan Pesantren Menurut Pemikiran Tuan Guru Kyai Haji Muhammad Zainuddin Abdul Madjid. Tesis Pasca Sarjana UIN Sunan Kalijaga, Yogyakarta. (http://digilib.uinsuka.ac.id/6932/1 /BAB\%20I\%2C\%20V\%2C\%20D AFTAR\%20PUSTAKA.pdf) diakses tanggal 17 Mei 2018.

Berger, Peter L and Luckmann, Thomas. 1967. The Social Construction of Reality A Treatise In The Sociology of Knpowledge. New York: Penguin Press

Bonita MK dalam Sadikin, Pipin Noviati., Arifin, Hadi Susilo., Pramudya, Bambang., Mulatsih, Sri. 2017. "Carrying Capacity to Preserve Biodiversity on Ecotourism in Mount Rinjani National Park, Indonesia". Biodiversitas. Vol.18, No. 3. hlm. 978-989. 
Cederroth, Sven. 1981. The Spell of The Ancestors And The Power of Mekkah A Sasak Community on Lombok. Sweden: Vasastadens Bokbinderi.

Darman, Faradika. 2017. "Representasi Manusia dan Alam dalam Puisi $\mathrm{Aku}$, Hutan Jati dan Indonesia Karya Yacinta Kurniasih". Totobuang, Vol.5, No. 2. hlm. $243-254$.

Hardiman. 2015. "Mengkreasi Produk Kajian Ekolinguistik terhadap Tradisi Lisan Kabjanti di Muna: Menuju ke Arah Penguatan Kajian Eco-Oral Tradition dalam Merayakan Keberagaman Tradisi Sebagai Warisan Budaya prosiding Seminar Internasional dan Festival Tradisi Lisan IX Wakatobi, 12--15 Juni 2015.

Jerome, Brunner. 1991. The Narrative Construction of Reality. In the Critical Inquiry 18. (Autumn 1991), The University of Chicago.

Lamadira, Asrif. 2015. "Mitos Imbu Pada Masyarakat Wakatobi". Tradition dalam Merayakan Keberagaman Tradisi Sebagai Warisan Budaya prosiding Seminar Internasional dan Festival Tradisi Lisan IX Wakatobi, 12--15 Juni 2015.

Riggs, Rebecca A., Langston, James D., Margules, Chris., Boedhihartono, Agni Klintuni ., She Lim, Han., Sari, Dwi Amalia., Sururi, Yazid., Sayer, Jeffrey. 2018. "Governance Challenges in an Eastern Indonesian Forest Lanscape". Sustainability, Vol. 10, No. 169

(www.mdpi.com/journal/sustainab ility), diakses tanggal 17 Mei 2018.
Riyanto, Geger. 2009. Peter L Berger Perspektif Metatoeri Pemikiran. Jakarta: LP3S

Suprapto. 2015. "Religious Leaders and Peace Building The Roles of Tuan Guru and Pedanda in Conflict Resolution in Lombok Indonesia". Al-Jāmi'ah: Journal of Islamic Studies. Vol. 53, no.1. hlm. 225250. DOI. 10.14421.

Taena1, La., Sailan, Zalili., Nalefo, La., Basri, Ali., Laepe, Ader., Samsul., Helmina, Siti., Miliha, La., Kuasa, Wa. 2016. "The Cultural Tradition of Falia in Preserving Forest by Munanese Ethnic". Journal of Sustainable Development. Vol. 9, No. 5. hlm. 200-206.

Wahyudewantoro, Gema. 2018. "The Fish Diversity of Mangorove Waters in Lombok Island, West Nusa Tenggara, Indonesia". Biodiversitas. Vol. 19, no.1. hlm. 71-76.

Zaelani, Kamaluddin. 2007. Satu Agama Banyak Tuhan. Mataram: Pantheon Media Pressindo.

Sumber Internet

Asia Ifada Org. 2012. Kerusakan Ekosistem Mangrove dan Upaya Pelestariannya di kabupaten Lombok Barat. https://asia.ifad.org/web/indonesia /home/-/news/6160/newsletter. Diakses 12 Desember 2015.

Yayasan Terumbu Karang Indonesia. Terumbu Karang: Manfaat Ekologi dan Ekonomi, Beserta Faktor Pengancamnya. https://www.slideshare.net/terangi 2011/terumbu-karang-manfaatekologi-dan-ekonomi-besertafaktor-pengancamnya. diakses 7 November

2015 